\title{
FURTHER EXPERIMENTS ON THE FERTILIZA- TION OF A SEA LOCH (LOCH CRAIGLIN). THE EFFECT OF DIFFERENT PLANT NUTRIENTS ON THE PHYTOPLANKTON
}

\author{
By S. M. Marshall, D.Sc. and A. P. Orr, M.A., D.Sc. \\ From the Marine Station, Millport
}

(Text-figs. I-IO)

\section{INTRODUCTION}

In 1942 and 1943 an experiment was made on the effect of adding nutrient salts to an isolated body of sea water. The experiment, which was initiated by Dr F. Gross of Edinburgh University and financed by Imperial Chemical Industries, Billingham Division, was carried out in Loch Craiglin, a small

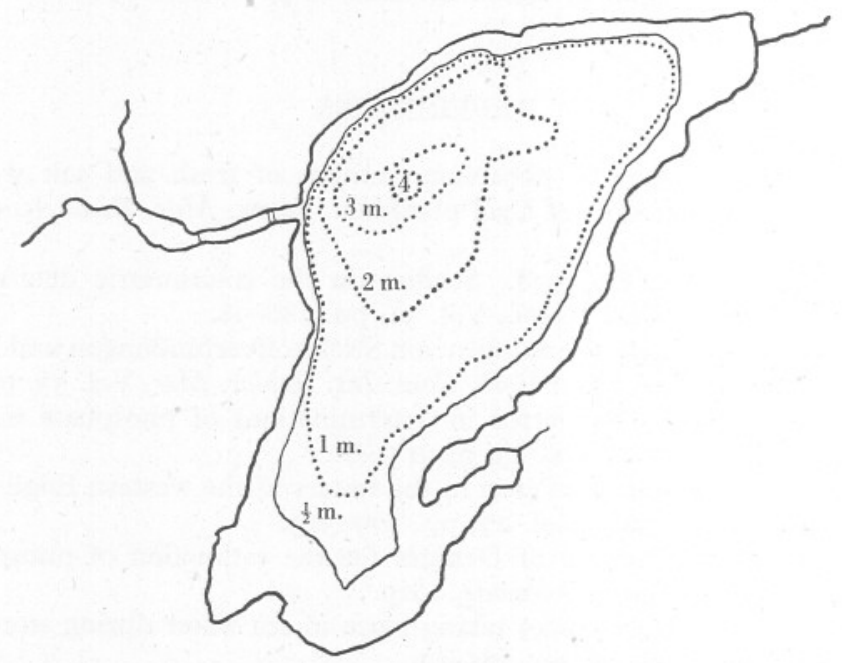

Fig. I. Sketch-map of Loch Craiglin showing approximate depth contours. Scale $15 \mathrm{~cm} .=1000 \mathrm{~m}$.

salt-water loch about eighteen acres in area and $70,000 \mathrm{~m} .{ }^{3}$ in volume opening off one of the arms of Loch Sween on the west coast of Argyll. It is connected with Loch Sween by a narrow channel and the entrance and exit of water could be partly controlled by a dam. Loch Craiglin (Fig. I) is shallow, most of it being less than $2 \mathrm{~m}$. in depth, although there is a small area up to $5 \mathrm{~m}$. deep opposite the mouth of the channel. The bottom is mostly soft mud but round the edge there are patches of sand or sandy mud. A small burn enters at the northeastern end. 
The plankton and hydrographic results from the first two years' work have already been described (Marshall, 1947; Orr, 1947) and it was shown that the addition of nutrients sometimes caused an immediate increase in the phytoplankton. In the early work the effect of the nutrients was assessed during visits made at about fortnightly intervals. The present paper deals mainly with a series of experiments in which the effect of added nutrients, both on the phytoplankton and on the hydrographic conditions, was followed from day to day.

We should like to express our thanks to Imperial Chemical Industries for their support, and also to our colleagues Dr F. Gross, Prof. J. E. G. Raymont, Dr D. T. Gauld and Mr S. R. Nutman for help in taking samples.

\section{MetHods}

The methods of chemical analysis and for sampling the plankton were the same as those described in the earlier papers.

There was considerable interference with the accuracy of the estimations of phosphorus and nitrogen compounds, both because of the richness in phytoplankton organisms and the presence of free sulphide in the deep water. To avoid damage to the glass electrode $\mathrm{pH}$ readings were not taken at $3 \mathrm{~m}$. when hydrogen sulphide was present.

During the fertilization experiments the number of $\mu$-flagellates in all water samples was counted daily on a haemocytometer slide without concentration. However, the fluctuations from day to day were so great that although some of the increases in numbers may be related to fertilizations, others were not and it is felt that a further study of the methods of counting and of the normal seasonal and diurnal variations in numbers is needed before any conclusions can be drawn. The numbers were, however, high when compared with counts from elsewhere, varying from a few hundred to several thousand per $\mathrm{mm} .^{3}$

Pump samples were taken on each visit in 1944 and once during each fertilization in 1945. The zooplankton on the whole was rather poor except for rotifers, and as might be expected showed no direct relation to fertilization. Oithona (chiefly $O$. nana) was the most abundant of the copepods.

Fertilizers were distributed by mixing up the solids with a large excess of loch water in a rowing boat and baling out the supernatant liquid into the loch. This was repeated until all had been distributed. It was spread as evenly as possible by rowing across the loch in a series of parallel lines while baling, but owing to wind and weather it was not always possible to keep accurate lines. Most of the nitrogen compounds dissolved readily but the superphosphate was not easily soluble and some of it certainly went to the bottom as solid. 


\section{FerTILIZATION EXPERIMENTS}

During the whole of the autumn and winter of 1943-44 the loch was rich in phytoplankton, mainly dinoflagellate, although there was a short outburst of diatom growth found on 26 November and II December. The dinoflagellate plankton consisted mainly of Peridinium triquetra and Gymnodinium spp., the diatoms of a minute form, Chaetoceros simplex, which Miss M. V. Lebour kindly identified.

The numbers of dinoflagellates continued to rise at the surface and at I $\mathrm{m}$. throughout December 1943 and January 1944 (Figs. 2, 3). A fertilization was made on I8 January with the usual quantities of sodium nitrate ( $142 \mathrm{lb}$.) and superphosphate ( $44 \mathrm{lb}$.) which is sufficient to raise the nitrogen and phosphorus from zero to well above normal winter sea values. The plankton was not examined again until 3I January when diatoms (minute Chaetoceros sp.) were very abundant and dinoflagellates had increased once more. They were almost entirely Peridinium triquetra and at the surface had reached a figure of $235^{\circ}$ per ml.

By 9 February diatoms had almost disappeared but dinoflagellates were still increasing. P. triquetra now numbered 3500 per $\mathrm{ml}$. at $\mathrm{o}$ and $\mathrm{I} \mathrm{m}$. and II 25 per ml. at $2 \mathrm{~m}$. A fertilization was made on II February using nearly three times the usual quantities of sodium nitrate $(336 \mathrm{lb}$.) and superphosphate (II $2 \mathrm{lb}$.) and the plankton was sampled on I9 February. The P. triquetra had increased to over 6000 per $\mathrm{ml}$. at the surface and $\mathrm{I} 730$ at $3 \mathrm{~m}$. but diatoms were practically absent. Seventeen days later on 7 March, P. triquetra had reached its maximum in the surface layer, 8165 per ml., but was scarce in deeper water and diatoms were still absent.

To find the amount of photosynthesis going on, samples of the phytoplankton-rich surface water were suspended in bottles at different depths on 20 February with similar controls kept in the dark. In spite of the enormous numbers of dinoflagellates, however, the oxygen production in these bottles over $24 \mathrm{hr}$. was negligible at all depths.

The numbers of dinoflagellates remained high, over rooo per ml., until the middle of June although the species present altered as time went on. On 9 April Gymnodinium spp. outnumbered Peridinium triquetra, though both were abundant. On 27 April this change had gone still further and Gymnodinium spp. had risen to $2435 \mathrm{per} \mathrm{ml}$. at the surface, while Peridinium triquetra had declined to 130 per ml. Gymnodinium remained predominant in May and June but at the beginning of July dinoflagellates had decreased to figures of 30 or 40 per $\mathrm{ml}$. At the end of June there was a sudden and short-lived increase in diatom numbers, again the minute Chaetoceros sp.

The number of 30 or 40 dinoflagellates per $\mathrm{ml}$. would be considered very high in normal sea plankton; it is low only in comparison with the extraordinarily high figures throughout the winter and spring in Loch Craiglin. The 


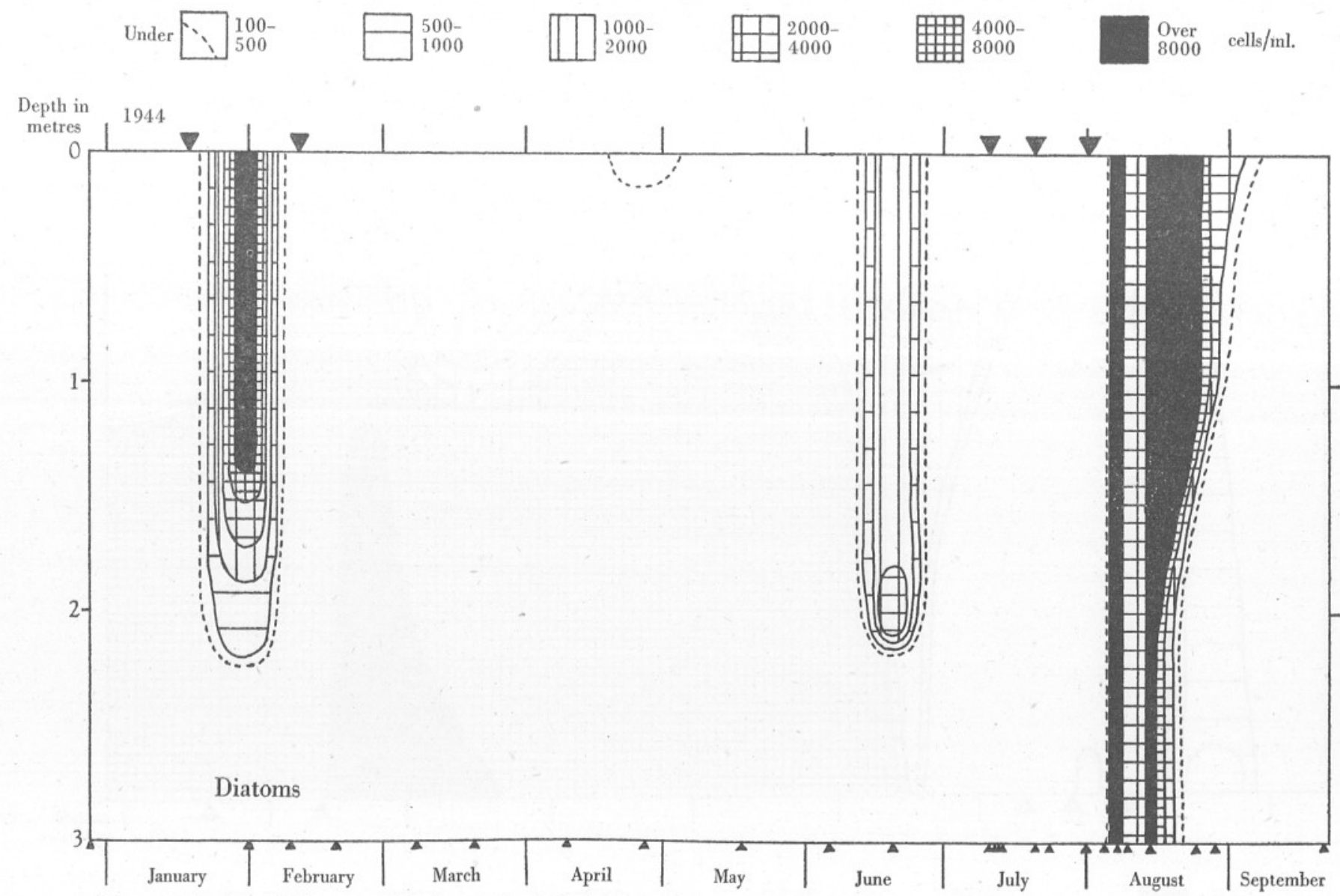

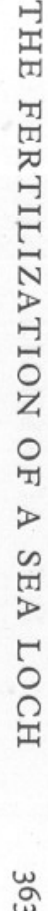

Fig. 2. Number of diatoms at Station I, Loch Craiglin, during I944. Large triangles above show dates of fertilizations; small triangles below show dates of sampling. 


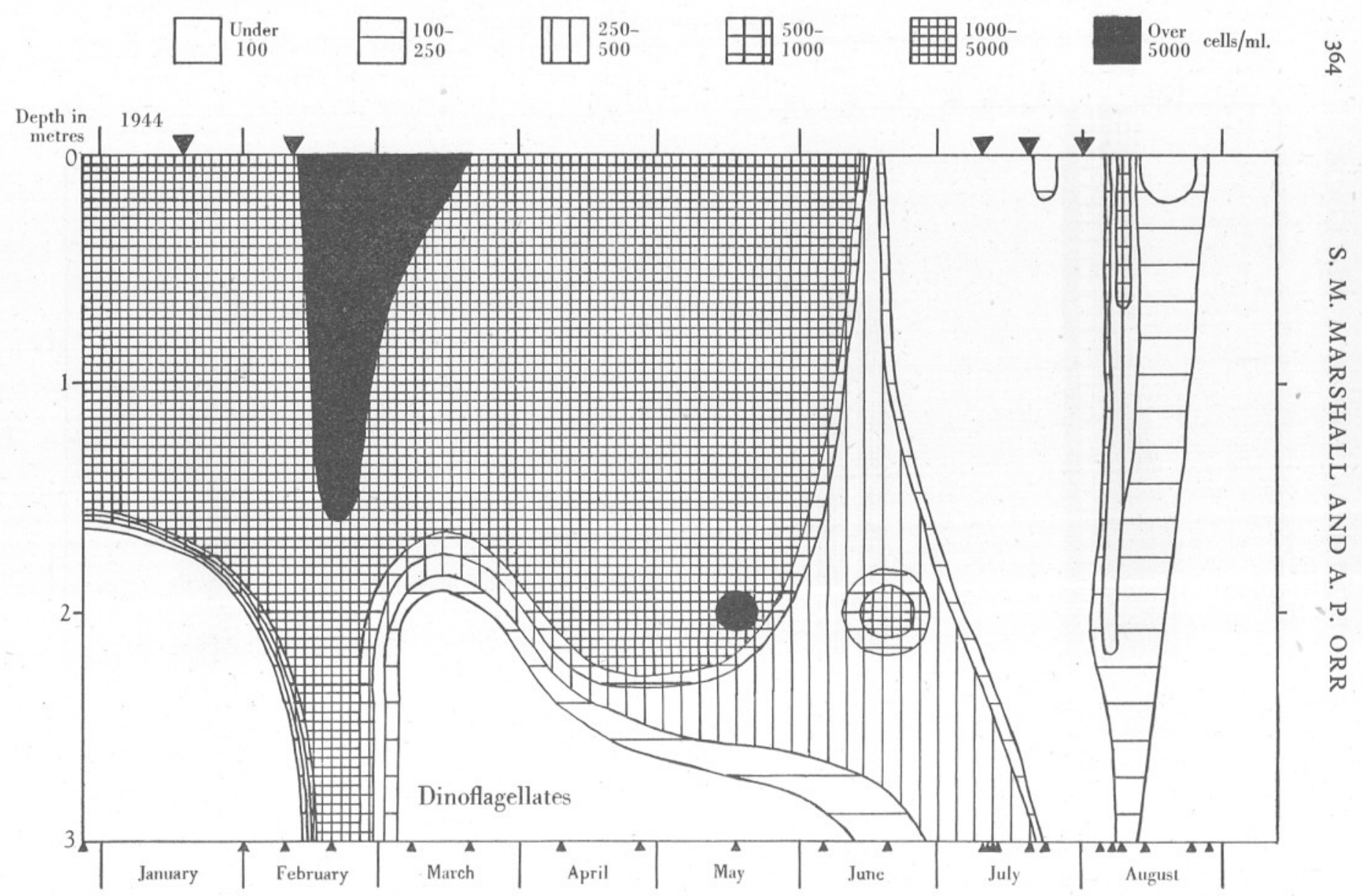

Fig. 3. Number of dinoflagellates at Station I, Loch Craiglin, during 1944. 
most abundant species, Peridinium triquetra, usually has a summer maximum and it is a form which, under favourable conditions such as in the polluted waters of the inner Oslo Fjord (Braarud, I945), is capable of increasing until it forms a 'waterbloom' or 'red water'. The maximum number recorded elsewhere, however, is a little below 3000 per ml.; in Loch Craiglin it rose to over 8000 per $\mathrm{ml}$. on two occasions, and remained above 2000 per $\mathrm{ml}$. for weeks on end. The water in the loch had during this period a distinct brownish red tinge.

There are several interesting points about these winter fertilizations. The first of them, on I8 January, was followed by a great increase of diatoms but dinoflagellate numbers, very high already, showed no comparable increase. On the other hand, the second fertilization on II February was followed by a decided increase in dinoflagellate numbers but had no effect on diatoms although the fertilizer added was nearly three times the usual amount. As a general rule in the open sea dinoflagellates follow diatoms in their times of maximum abundance and they are said (Barker, I935) to be able to use lower concentrations of nutrients than the former. It is therefore surprising to find an increase of diatoms ( 19 June) following immediately upon the dying away of dinoflagellates.

The plankton in Sailean More, the open arm of Loch Sween with which Loch Craiglin is connected, showed no comparable changes; dinoflagellates were scarce throughout and, although there was a great rise in diatom numbers in April (over 2000 per ml. at I m. on 27 April), the form was a Leptocylindrus sp. The minute Chaetoceros sp. so characteristic of Loch Craiglin did not appear in Sailean More.

A curious feature of the spring of 1944 in Loch Craiglin was that the phytoplankton remained rich throughout the spring months when, in other years, fertilizations at that time had little or no effect on the phytoplankton because the attached vegetation seemed to have first call on the nutrients.

In July and August a series of fertilizations was begun and each was followed up by sampling at short intervals, usually I or 2 days (Figs. 4-6). The first fertilization was made with superphosphate alone, the second with nitrate alone and the third with ten times the usual quantity of both.

During these months there was a rich vegetation, consisting partly of algae (chiefly Enteromorpha and Cladophora) and partly of Zostera and Ruppia, round the shores and this interfered considerably with the experiments.

On Io July, $66 \mathrm{lb}$. superphosphate was added. This caused a rise in soluble phosphate chiefly at the surface which lasted for only 2 or 3 days. The $\mathrm{pH}$ and percentage oxygen saturation rose after the fertilization, in agreement with the utilization of the soluble phosphate, though the highest figure for oxygen ( $150 \%$ saturation) was at I $\mathrm{m}$. At the surface equilibrium of oxygen with the air seems to be reached rapidly. Nitrate was present down to $2 \mathrm{~m}$. and although it was only in small quantities it does not seem probable that it was a limiting factor. 
This fertilization had no visible effect on the phytoplankton. Dinoflagellates were present in fair numbers but diatoms were absent. This suggests that

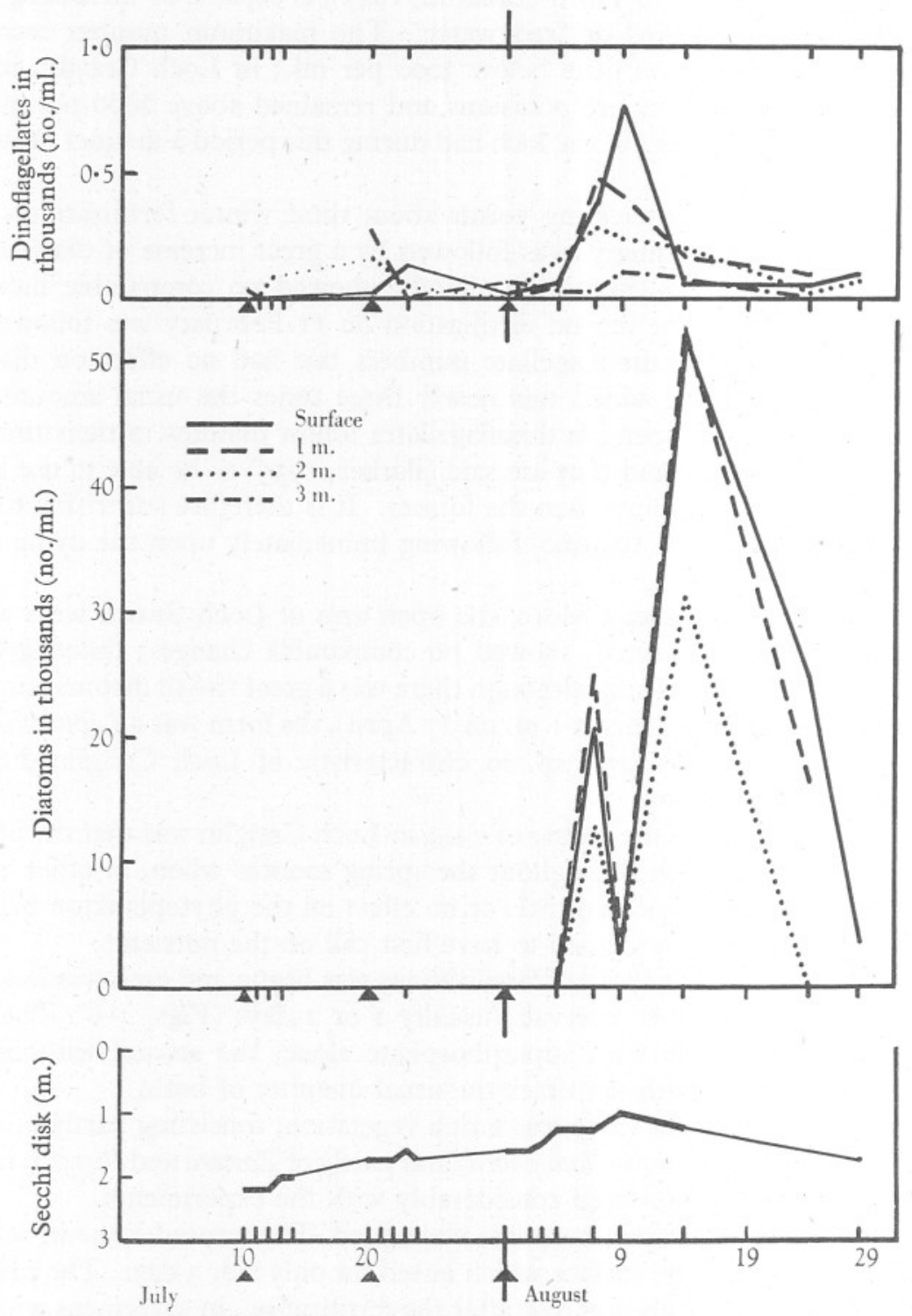

Fig. 4. Effect on the phytoplankton and the transparency of the water of fertilizations during July and August I944. Triangles below show dates of fertilizations.

the vegetation round the shore and in shallow water was absorbing all the nutrients. 
On $20 \mathrm{July}, \mathrm{I} 4 \mathrm{I} \mathrm{lb}$. sodium nitrate was added. This caused a rise in nitrate- $\mathrm{N}$ at all depths. Values remained high for $3-4$ days but after a week were back to normal. Percentage oxygen saturation and $\mathrm{pH}$ were high except in deep water; the values were affected by slight salinity changes caused by an influx of water from Sailean More.
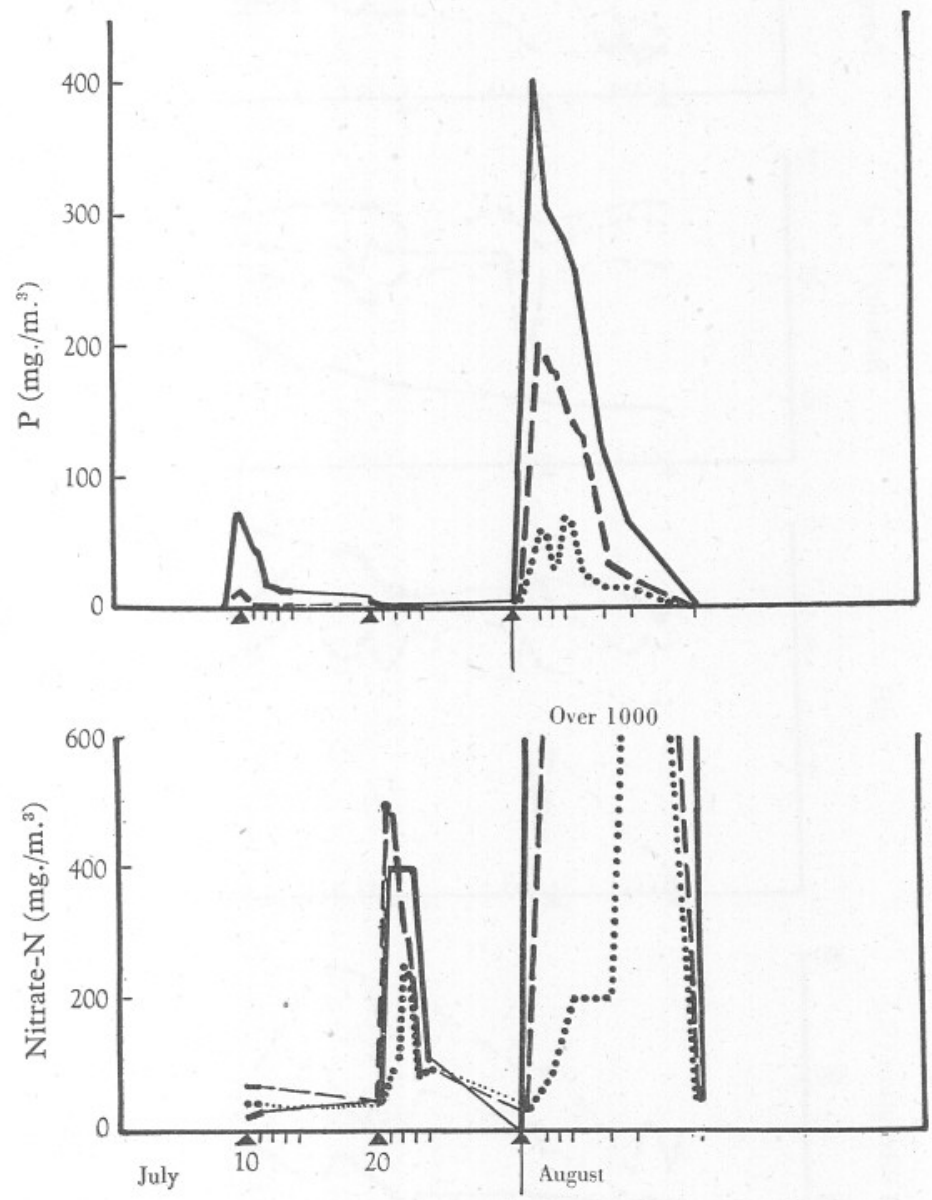

Fig. 5. Changes in nutrient salt concentrations during fertilizations in July and August I944. Depths marked as in Fig. 4 .

Although there was apparently a slight increase of dinoflagellates (naked forms, mainly Gymnodinium spp. and Oxyrrhis marina), this is probably not significant, since the numbers actually fell at $\mathrm{I} \mathrm{m}$. from 20 to 23 July.

The fertilization with about ten times the usual quantity of nutrients ( $1344 \mathrm{lb}$. sodium nitrate and $448 \mathrm{lb}$. superphosphate) was done on I August. This raised the dissolved phosphate up to $400 \mathrm{mg} . / \mathrm{m}^{3}$ at the surface and to high 

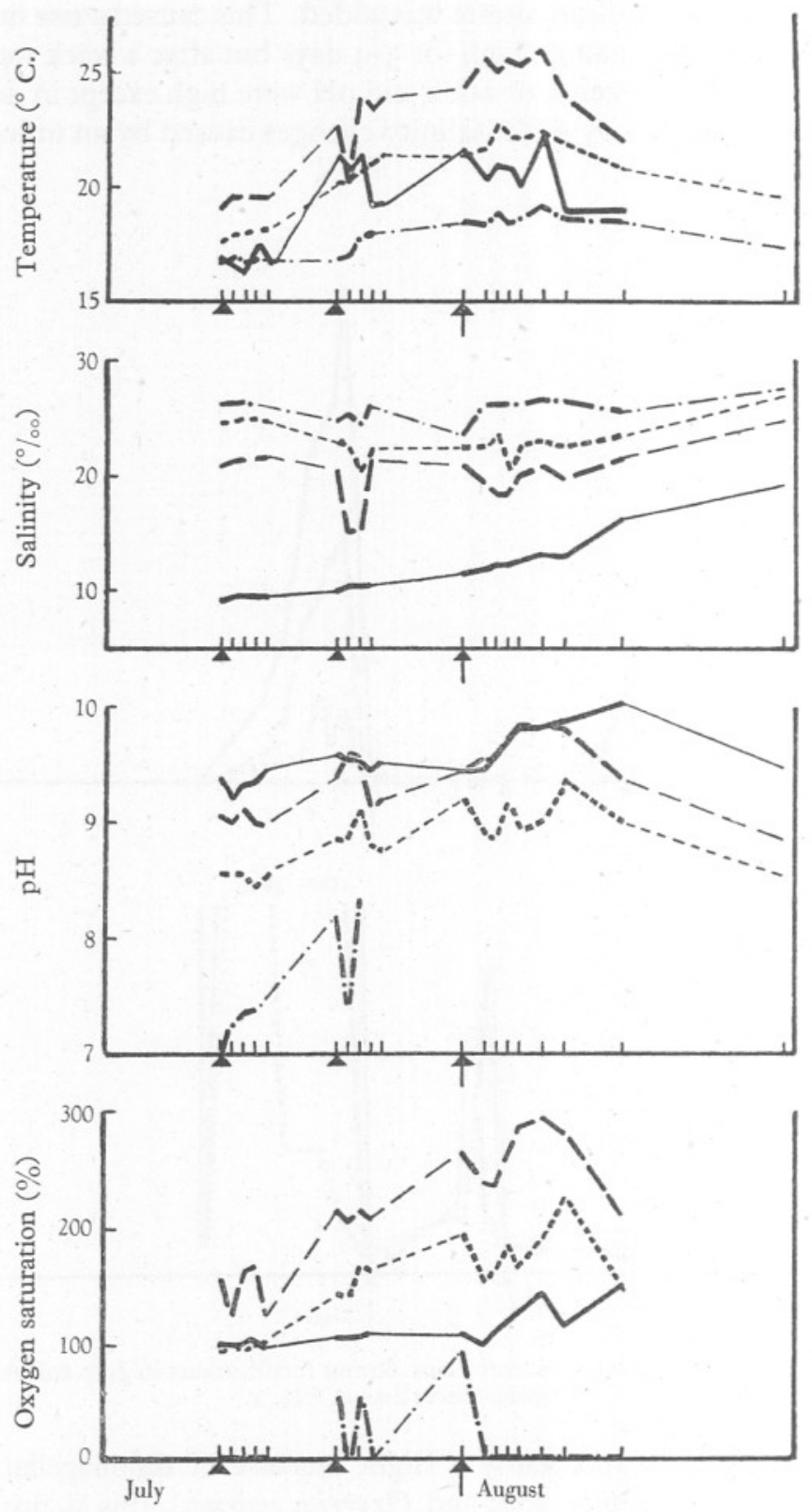

Fig. 6. Hydrographic and chemical changes during fertilizations in July and August 1944. Depths marked as in Fig. 4. 
values in deeper water also. Utilization was rapid and in less than a fortnight values were back to normal. A rise in $\mathrm{pH}$ and percentage oxygen saturation coincided with the utilization of the soluble phosphate. Nitrate- $\mathrm{N}$, very high immediately after fertilization, fell to normal within a fortnight.

Phytoplankton was very poor on the day of fertilization and for several days after, but on the seventh day after fertilization, diatoms were present in large numbers at all depths. There was a curious and unexplained fall in numbers (not confirmed by Secchi disk readings) on 9 August, but on the I4th the numbers were very high indeed (just over 50,000 cells $/ \mathrm{ml}$.) and thereafter fell rapidly. Three species took part in the increase, Chaetoceros simplex, a minute Naviculid and the triradiate form of Nitzschia closterium. Dinoflagellates also became abundant. Their numbers rose from 3I July to 4 August and again from the 4 th to the 9 th after which they fell. Exuviella marina was the commonest form, but Gymnodinium spp. also increased.

Compared with the first two fertilizations this one did produce a large increase in the phytoplankton, but only after a lapse of 4 days for dinoflagellates and of 7 days for diatoms.

The results of these three fertilizations suggest that only when the needs of the attached algae have been satisfied can the phytoplankton utilize any remaining nutrients. During the nitrate fertilization, however, the very low phosphate may have been a limiting factor. It is also possible that some of the nutrients are adsorbed by the mud or by non-living material suspended in the water. This would explain their very rapid disappearance.

The above experiments, as well as earlier work in this loch (Marshall, I947; Orr, I947), indicate that when shore-living algae are growing, fertilization does not result in an increase in phytoplankton except when very large quantities of nutrients are used.

During the winter the attached algae are absent or dormant but there is still enough light to permit photosynthesis in the shallow water of Loch Craiglin. A series of experiments was therefore carried out during the winter months to find whether other forms of inorganic phosphorus and nitrogen besides nitrate and superphosphate could be used by the phytoplankton (Figs. 7-9). The following combinations were tested:

(I) Superphosphate and sodium nitrate as normally.

(2) Superphosphate and ammonium sulphate.

(3) Superphosphate and ammonium nitrate.

(4) Mono-ammonium phosphate and ammonium sulphate.

The salts used were all available commercially as fertilizers, but were nevertheless of high quality.

Ammonium salts were chosen both because of the biological interest of testing whether ammonia-nitrogen could be used directly by the phytoplankton and because it is one of the commonest artificial fertilizers applied to land and so available in large quantities. Ammonium nitrate is used as an explosive and 

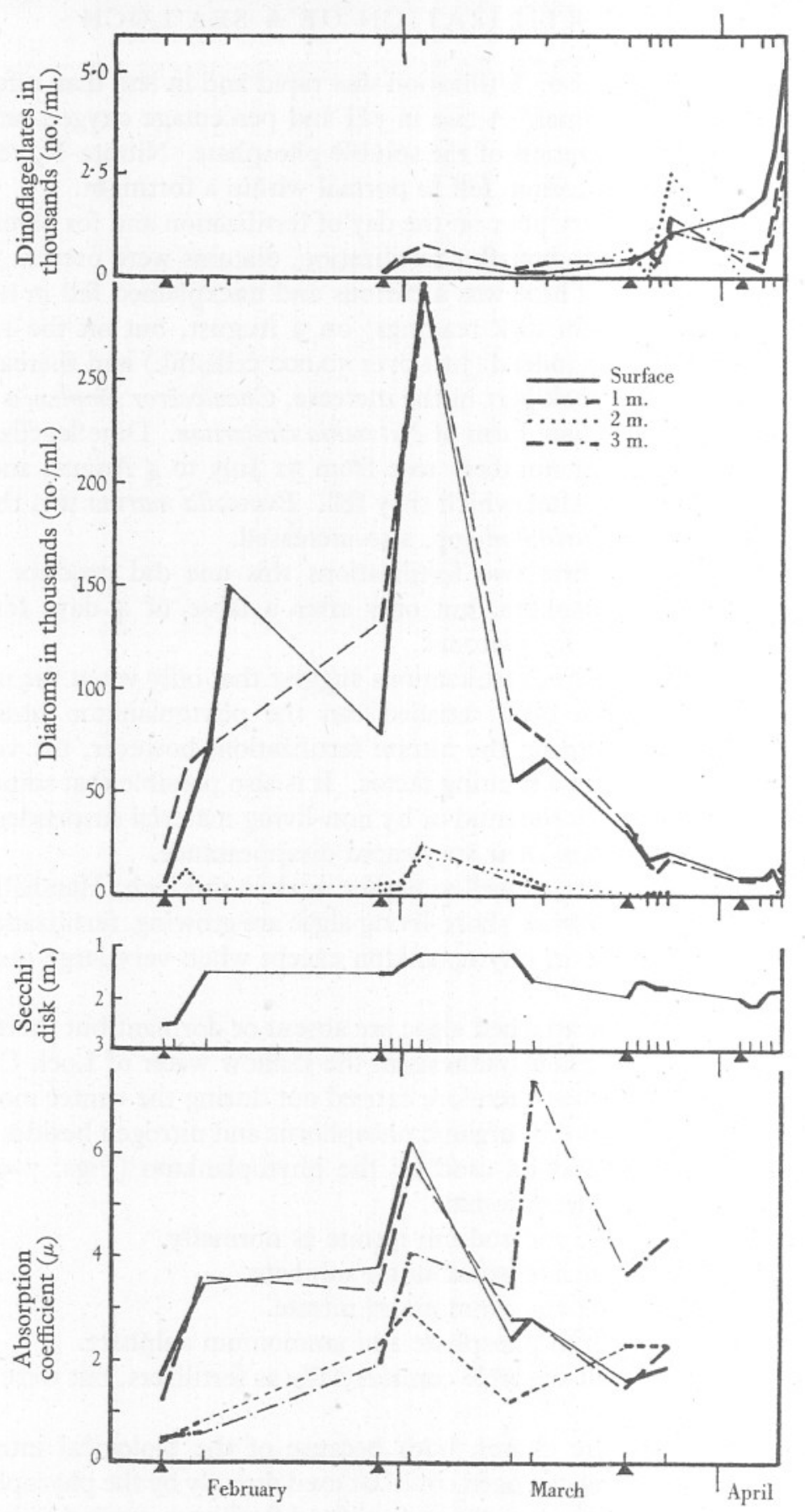

Fig. 7. Effect on the phytoplankton and the transparency of the water of fertilizations during February to April 1945. 

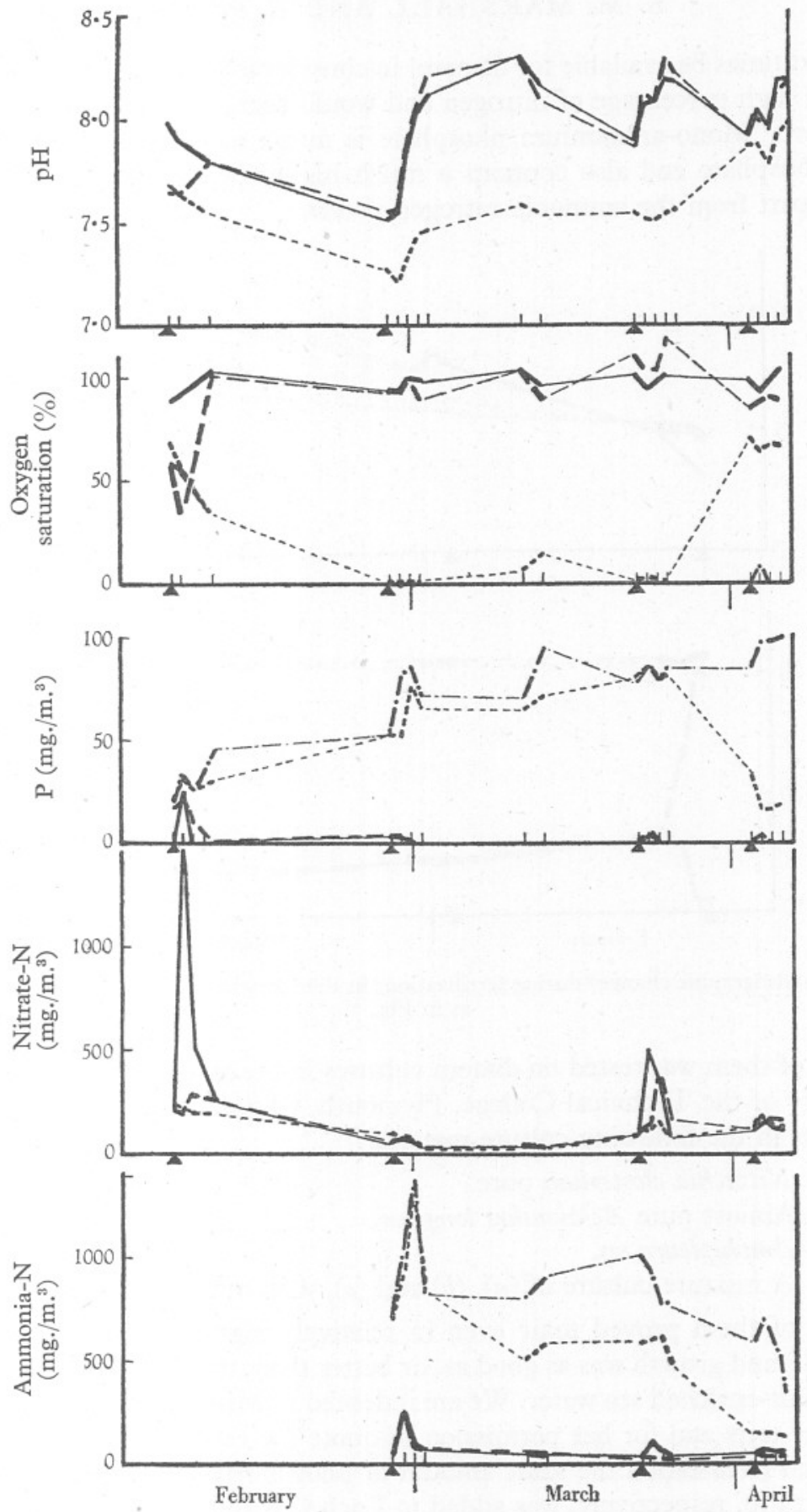

Fig. 8. Changes in nutrient salts and other chemical factors during fertilizations in February to April 1945. Depths marked as in Fig. 7 . 
might at times be available for disposal in considerable quantities. In addition it has a high percentage of nitrogen and would therefore be less expensive to transport. Mono-ammonium phosphate is much more readily soluble than superphosphate and also contains a much higher percentage of phosphorus quite apart from the ammonia-nitrogen present.
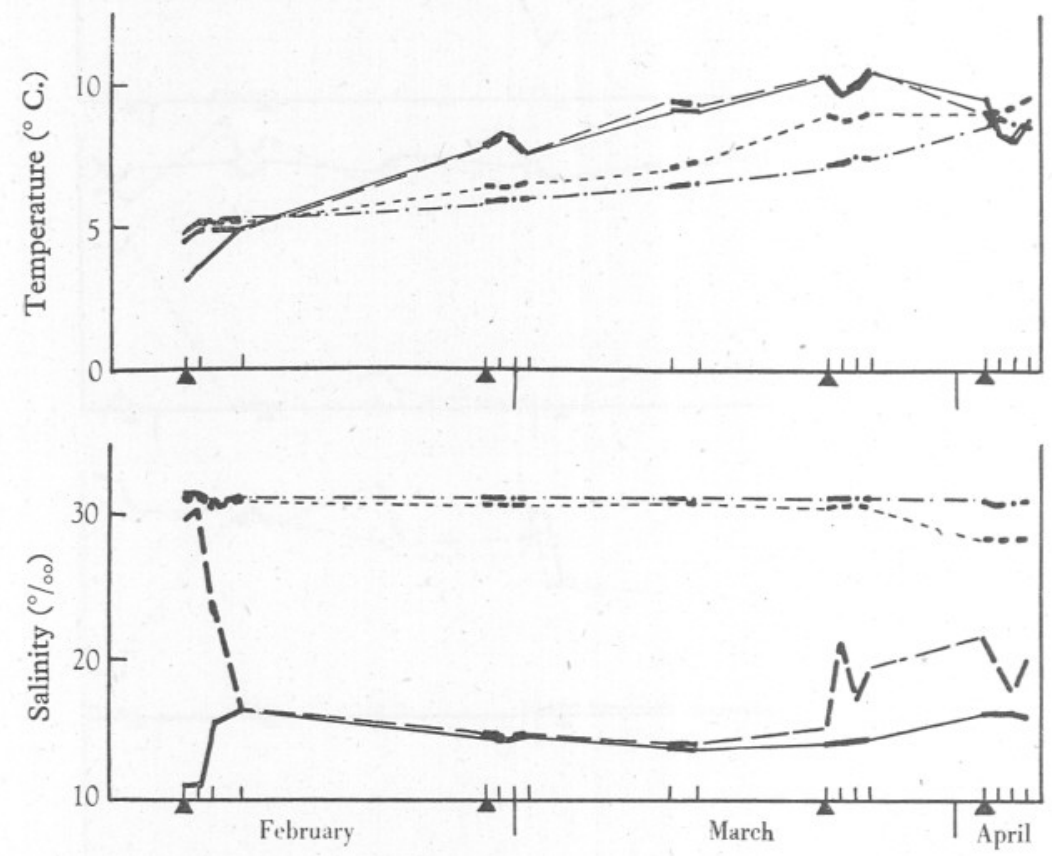

Fig. 9. Hydrographic changes during fertilizations in February to April 1945. Depths marked as in Fig. 7.

Each of them was tested on diatom cultures in the laboratory by Miss F. A. Stanbury of the Technical College, Plymouth, who used them as a source of nutrients in the following culture material:

(a) Nitzschia closterium pure.

(b) Almost pure Achnanthes longipes.

(c) Amphipleura sp.

(d) A mixture culture of $(a),(b)$ and (c), with other forms.

None of them proved toxic even in relatively high concentrations (up to $25 \mathrm{mg}$./1.) and growth was as good as, or better than, that in controls in 'aged' or nutrient-enriched sea water. We are indebted to Miss Stanbury for carrying out these tests and for her permission to quote the results.

In each fertilization the same amount of phosphorus and nitrogen, namely 3.4 and $23 \mathrm{lb}$. respectively, was added to Loch Craiglin. This was roughly the same as in the normal fertilizations with sodium nitrate and superphosphate 
and was enough to raise the concentration to well above average winter sea values.

During the winter the dam was open to allow interchange with the main loch outside, and aeration of the deep water was fairly good. The dam was closed on 5 February 1945 and the normal amounts of fertilizers added that afternoon in the form of sodium nitrate and superphosphate. Phosphate was initially high at I, 2 and $3 \mathrm{~m}$. and after the fertilization rose at all depths. The day following fertilization, however, soluble phosphate dropped to zero at the surface and 3 days later was absent at $\mathrm{I} \mathrm{m}$. Nitrate gave winter values at the surface before fertilization and increased afterwards only at the surface. The following day it fell abruptly at the surface and 2 days later values were only slightly above normal winter concentrations.

During the course of the experiment changes in salinity showed that the surface and I $\mathrm{m}$. layers had mixed. This affected the $\mathrm{pH}$ and percentage oxygen saturation values at these depths.

Diatoms (Chaetoceros simplex) were abundant in the loch before fertilization ( 5300 cells $/ \mathrm{ml}$. at the surface and 22,500 cells $/ \mathrm{ml}$. at I m.), and increased afterwards to $\mathrm{I} 49,000$ per $\mathrm{ml}$. at the surface on the IIth. Dinoflagellates were scarce and showed no significant change. This enormous production affected the transparency of the water considerably. The Secchi disk which initially was visible down to $2 \frac{1}{2} \mathrm{~m}$. was visible only to $\mathrm{I} \frac{1}{2} \mathrm{~m}$. on the 9 th. Measurements of the absorption coefficient with the Pulfrich absorptiometer showed a rise from $\mathrm{I} \cdot 7$ and $\mathrm{I} \cdot 3$ at $O$ and $\mathrm{I} \mathrm{m}$. on the 5 th to 3.5 and 3.7 on the 9 th. In deeper water there was little change (Fig. 7).

On 26 February the loch was fertilized again with $42 \mathrm{lb}$. superphosphate and IIO lb. ammonium sulphate. In spite of this addition no phosphate appeared at the surface or $\mathrm{I} \mathrm{m}$. although there was a rise below this at 2 and $3 \mathrm{~m}$. where the phosphate value had in any case remained high since the previous fertilization. This immediate disappearance of added nutrients was found on several occasions and is not understood. The rapidity suggests that absorption either by the phytoplankton and fixed algae, or else adsorption by dead particulate matter, is responsible.

The added ammonium sulphate did cause an increase, though a small one, in the ammonia present at the surface and I $\mathrm{m}$. as well as a greater increase at 2 and $3 \mathrm{~m}$. Nitrate remained low. All the nutrients had fallen to their original level in 2 days.

At no other time was a fertilization made when phytoplankton was initially so abundant. Although numbers had fallen at the surface from II February, they had risen at I $\mathrm{m}$. and at both these depths were very high indeed (77,000 cells of Chaetoceros simplex per ml. at the surface and I33,000 at I m.). These high numbers rose still further on succeeding days; on 28 February there were over 200,000 and on 2 March nearly 300,000 cells $/ \mathrm{ml}$. down to I m. At 2 and $3 \mathrm{~m}$. numbers were much lower ( 18,000 and $24,000 \mathrm{cells} / \mathrm{ml}$. respectively). 
Dinoflagellates were relatively unimportant but did show a slight increase. Oxyrrhis marina was the most abundant species.

Accompanying the great increase in diatoms there was a sharp rise in $\mathrm{pH}$ in the surface layers from $7 \cdot 6$ to $8 \cdot 3$, and there was a slight effect even at $2 \mathrm{~m}$. The change, however, in percentage oxygen saturation was small. The transparency of the water, which was initially the same as at the end of the previous fertilization, showed an abrupt decrease, especially at the surface and I m. By I March the water was very turbid indeed, the absorption coefficient being $6 \cdot 2$ and 5.8 at $\mathrm{O}$ and $\mathrm{I} \mathrm{m}$. respectively.

The results of this fertilization confirm the findings in the laboratory of Harvey (1933) and ZoBell (1935) that ammonium salts can be used directly by the phytoplankton.

In Loch Craiglin (of which the greater part is less than $2 \mathrm{~m}$. in depth) photosynthesis can go on down to the bottom even in winter providing there is a sufficiency of plant nutrients, and the mere closing of the dam might be enough to start off a phytoplankton increase by cutting down interchange with the outside loch and enclosing, in winter, nutrient-rich water. In an attempt to test this, the dam was left open from 2 to II March. It was closed that day and samples were taken then and 3 days later. The hydrographic data show, however, that there had been very little interchange with outside owing to poor tides and there was also no significant change in the phytoplankton in the 3 days although it had decreased greatly from the maximum on 2 March. The experiment therefore failed in its object.

On 22 March a fertilization was made using $42 \mathrm{lb}$. superphosphate and $67 \mathrm{lb}$. ammonium nitrate. The added phosphate had, as after the previous fertilization, disappeared before samples were taken the following day. Ammonia and nitrate, however, showed an increase at the surface which lasted for 2 days. Diatom numbers had fallen still further from I4 March and continued to do so in spite of the fertilization, although there were still between I0,000 and 30,000 per ml. present at the surface and I m. Dinoflagellates on the other hand showed a distinct increase at the surface. The form causing it was a Gymnodinium sp. and Oxyrrhis marina was numerous on the 26 th at 2 and $3 \mathrm{~m}$.

That appreciable photosynthesis had taken place was shown by the abrupt rise in $\mathrm{pH}$ at the surface and $\mathrm{I} \mathrm{m}$. immediately following fertilization. The attached algae were noted as just beginning to grow and, since the rapid rise in $\mathrm{pH}$ and the disappearance of the nutrients are much more than could be accounted for by the comparatively small numbers of diatoms and dinoflagellates present, it is probable that the attached algae were responsible. This is confirmed also by the transparency measurements which show only a slight decrease when compared with previous fertilizations.

On 2 April a fertilization was made using I2.4 $\mathrm{lb}$. mono-ammonium phosphate and Io $_{3} \mathrm{lb}$. of ammonium sulphate. Neither the phosphate nor the ammonia 
showed any appreciable increase when the loch was sampled the following day. Hydrographic conditions were not very stable but there was a marked rise in $\mathrm{pH}$. Diatom numbers had fallen still further since the last fertilization and remained steady at about I0,000 cells $/ \mathrm{ml}$. Chaetoceros simplex still predominated although Thalassiosira nana was also numerous. Dinoflagellates had increased at the surface and decreased at $\mathrm{I} \mathrm{m}$. since the last visit but fertilization resulted in a marked rise at both depths, up to nearly 5000 and 3400 cells $/ \mathrm{ml}$. at o and I m. respectively. Gymnodinium spp. were again mainly responsible. On this occasion the Pulfrich absorptiometer was not available and the transparency was measured by the Secchi disk only; it showed a slight decrease. In the earlier fertilizations there was a good agreement between the phytoplankton and the Secchi disk readings (Fig. 4).

By now, April, the attached algae were obviously competing successfully with the phytoplankton for nutrients and the testing of the remaining nitrogen salts (ammonium chloride and urea) was deferred till the following winter. The algae remained rich during the summer of 1945 and were still abundant in the autumn so that it was not till January I 946 that it was considered safe to do further fertilizations.

The loch was then in a condition very different from what it had been in I945. Phytoplankton was very scarce with numbers of only Io or 20 cells $/ \mathrm{ml}$. as against the thousands of the previous year. In addition plant nutrients, though not abundant, were present in sufficient quantity to allow plant growth. As in $1944-45$, the dam had been opened during the autumn months and was closed at the end of December so that the great difference in the quantity of plankton in the 2 years cannot be explained thus.

A fertilization was made on Io January with $42 \mathrm{lb}$. superphosphate and II 2 lb. ammonium chloride and another on 23 January with 42 lb. superphosphate and $56 \mathrm{lb}$. urea. At neither time was there any increase in the phytoplankton, nor was there any important increase in the amounts of nutrients in the water although there was a short-lived rise in soluble phosphorus at the surface after the second fertilization.

At the time of the first fertilization the loch level was unusually high and it fell rapidly during the following days; it was estimated that the loss during the period of this fertilization amounted to about a third of the total volume of Loch Craiglin. Some of the fertilizer must undoubtedly have been lost in this way and it may partly account for the lack of any increase in nutrients. During the second fertilization there was no appreciable change in loch level.

The reason for the failure of these two fertilizations to produce a phytoplankton increase is not known, but several suggestions can be made. Compared with I945 there was an insignificant number of diatoms present initially and although the shore algae appeared to be negligible, the proportion of diatoms to attached algae may still have been too small for the diatoms to compete successfully for the nutrients. On the other hand, the fact that 
nutrients were present before fertilization seems against this explanation. The considerable fall in loch level may have carried away both the nutrients and the phytoplankton.

The weather was unfavourable for diatom growth; during the first experiment the loch was frozen over several times and the light thus cut down; during the second it was overcast, wet and stormy. In view of the success of Miss Stanbury's tests which were made on these fertilizers also, it seems unlikely that they were at fault, though she noted a delay in diatom growth with urea as a source of nitrogen when compared with the others.

It must be admitted, however, that none of these explanations is very convincing and that there may be other factors, of which nothing is known, playing a more important part.

Diurnal variation. In shore pools there is normally a considerable diurnal fluctuation in hydrographic conditions and it was thought that this might be true in Loch Craiglin also. In conjunction with an experiment on the vertical migration of Euglena (see below), samples of the water were taken at a series of depths every $4 \mathrm{hr}$. over $24 \mathrm{hr}$. in August. The weather was calm and bright. During the period of the experiment a high tide in Sailean More caused an influx of open loch water which would affect the results. There was an appreciable diurnal temperature range at the surface which was still noticeable at $\mathrm{I} \mathrm{m}$. The changes in $\mathrm{pH}$ value and percentage oxygen saturation are, however, not related to light and dark at Station I as was expected. Samples taken close inshore where Ruppia was growing luxuriantly did show a rise in $\mathrm{pH}$ during the day up to nearly Io. A point of interest was the peak in oxygen saturation at $4 \mathrm{p} . \mathrm{m}$. at $2 \mathrm{~m}$. which may be related to the abundance of Euglena at that depth.

Occurrence of Euglena. Occasionally in Loch Craiglin very large numbers of a species of Euglena (kindly identified by Prof. F. E. Fritsch as E. proxima) were present. These were comparatively large (about $70 \mu$ long) and might be present in such numbers that the water samples were bright green. Although holotrophic they never appeared in numbers at the surface and were usually most common at or near the boundary between oxygenated and oxygen-free water. They were often found richest in samples smelling of hydrogen sulphide but the numbers fluctuated widely from one depth to another and from day to day so that they apparently occupied a rather narrow zone. They occurred both in winter and in summer although the highest numbers (40,000-54,000 per ml.) were in summer.

Because of this peculiar depth distribution it was thought that their light requirements might be low and that they might migrate towards the surface at dusk and dawn. A series of pump samples was therefore taken at four depths at 4 -hr. intervals, from 8 a.m. on 4 August to 4 a.m. on 5 August I944.

To ensure that the whole water column was sampled fairly evenly, the mouth of the hose in taking each sample was rapidly raised and lowered between 
$O$ and I, I and 2, 2 and 3 or 3 and $4 \mathrm{~m}$. until an adequate amount (about 7 1.) had been taken from each depth. This was well shaken and a subsample drawn off and preserved. The results (Fig. Io and Table I) were unexpected and are not easy to explain. At no time did the Euglena appear in numbers in the water above $2 \mathrm{~m}$. They were always most numerous between 2 and $3 \mathrm{~m}$. except at 4 a.m. when there were slightly more between 3 and $4 \mathrm{~m}$. than between 2 and $3 \mathrm{~m}$. During the course of the experiment there was a slight increase in total numbers at I2 noon but a steady decrease thereafter so that at 4 a.m. there were only a little more than a third of the maximum number.

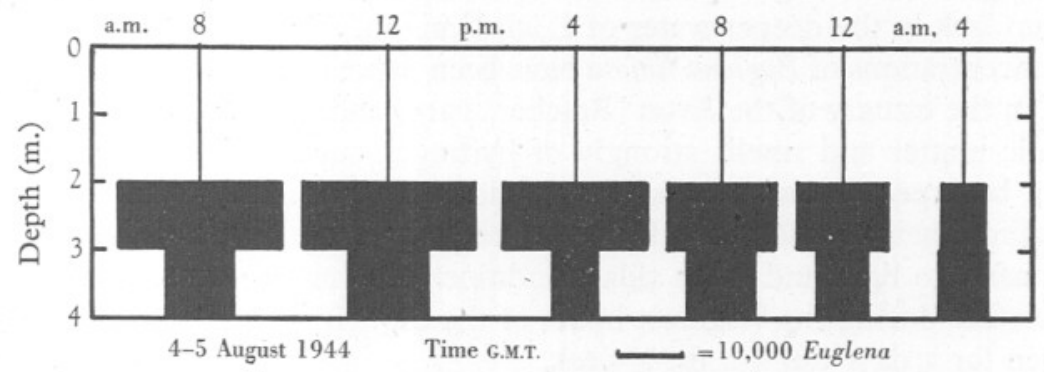

Fig. Io. Vertical distribution of Euglena proxima over a 24-hr. period 4-5 August 1944.

Table I. Diurnal variation In NUMbers of EUGLENA (No./ML.)

\begin{tabular}{lrrrrrr} 
Depth & \multicolumn{6}{c}{ Time } \\
in m. & 8 a.m. & I2 noon & 4 p.m. & 8 p.m. & I2 midnight & 4 a.m. \\
O-I & 25 & Lost & I0 & 25 & 50 & 25 \\
I-2 & 5 & 5 & 0 & 5 & 15 & I5 \\
$2-3$ & 24,500 & 26,000 & 21,500 & 16,000 & 13,000 & 6,250 \\
$3-4$ & 10,500 & 12,000 & 7,000 & 10,000 & 7,500 & 7,500
\end{tabular}

The Euglenids obviously do not carry out any appreciable diurnal vertical migration but it is difficult to understand the variation in numbers. They may occur in swarms and a small difference in position may make a large difference in numbers.

Since in spite of their green colour they live so deep in the water, an opportunity was taken when they were numerous of measuring their respiration and photosynthesis. On 23 July 1944 a large sample of water from $3 \mathrm{~m}$. containing 22,400 Euglena/ml. was thoroughly stirred to oxygenate it and the changes in oxygen content both in light and dark measured over a period of $4 \mathrm{hr}$. in the afternoon (I2.I5-4.I5 p.m. G.M.T.) at a depth of I m. Samples for the initial oxygen content were drawn off and the samples for light and dark exposure put in bottles, the latter enclosed in opaque black cloth. The bottles in the light showed an oxygen rise of about $0.3 \mathrm{I} \mathrm{ml.} \mathrm{O}_{2} / 1$. whereas those in the dark showed a consumption of $\mathrm{r} \cdot 83 \mathrm{ml} . \mathrm{O}_{2} / 1$. This is equivalent to a total oxygen production of $0.024 \mathrm{ml}$. oxygen per hour per million Euglena. It is 
obvious that although this Euglena does carry on photosynthesis, the oxygen thus produced even at a depth of I $\mathrm{m}$. is much exceeded by that used up in respiration. Over the whole day, at the depth where they normally occur, photosynthesis must play only a very small part in their metabolism. This was confirmed by an experiment done the previous day when samples of water from each depth (o, I, 2 and $3 \mathrm{~m}$.) were shaken well to oxygenate them and the oxygen utilization in the dark measured after $24 \mathrm{hr}$. The utilization was small at the surface (0.I4 ml./1.), slightly greater at I and $2 \mathrm{~m}$. (0.I8 and $0.38 \mathrm{ml}$./1.) and rose suddenly to $\mathrm{I} \cdot 74 \mathrm{ml}$./1. in the $3 \mathrm{~m}$. sample which was slightly green with Euglena. The Euglena undoubtedly are at times partly responsible for the oxygen lack in the deeper water of Loch Craiglin.

Concentrations of Euglena limosa have been described on the surface of tidal mud in the estuary of the Avon (Bracher, I9I9) and, since this mud is rich in organic matter and smells strongly of hydrogen sulphide when disturbed it might be expected that the Euglena would behave similarly to those in Loch Craiglin. Their reactions are, however, very different. Euglena limosa is very responsive to light and when tidal conditions are suitable comes up to lie on the surface during the brightest hours of the day. It is able to survive lack of oxygen for 3 days but not for a week.

\section{SUMMARY AND CONCLUSIONS}

Loch Craiglin cannot be considered as merely an isolated basin of Loch Sween. Its shallowness, the great growth of vegetation round the shore and the fluctuations in salinity make it atypical. On the more complete isolation of the loch with the making of the dam, these conditions led to a lack of circulation, a consequent development of hydrogen sulphide in the deep water and very high $\mathrm{pH}$ values near the surface. One could not therefore expect the plankton to be very similar to that in the outside loch (see, however, Marshall, I947). Unfortunately there are no records of seasonal variation before fertilization was begun. In spite of these drawbacks Loch Craiglin was a convenient and manageable area for small-scale experiments on fertilization.

The experiments may be divided into two groups, those which were not followed up in detail and those in which the plankton and hydrographic results were followed from day to day. The former, made during the earlier stages of the work, are mainly described in the previous papers and led to the conclusion that the richness in phytoplankton of Loch Craiglin in I943 was probably caused to a large extent by fertilization. Those of the second group, described above, were made to test special points and different fertilizers. Two experiments made during the summer of I944 had apparently no effect on the phytoplankton but a third in which a very large excess of fertilizer (ten times the normal quantity) was added, gave a good increase after an initial lag. At that time the attached algae were abundant and their needs apparently had to be satisfied before any nutrients could be used by the phytoplankton. 
The remaining experiments, which were therefore made during the winter, showed that commercial ammonium sulphate, ammonium nitrate and monoammonium phosphate could replace the sodium nitrate and superphosphate used hitherto. Two further experiments in the following spring using ammonium chloride and urea did not, however, prove effective. All the salts used had been found in laboratory tests by Miss F. A. Stanbury to be suitable for diatom growth, and the reason for the failure of these two in the loch is unknown.

The utilization of the nutrients was extremely rapid even in winter but it is probable that their disappearance is not entirely caused by the phytoplankton or bottom-living algae but partly by adsorption on the bottom mud or by suspended matter. On one occasion it may have been caused by a serious fall in loch level.

The zooplankton which during the first year of fertilizations was richer in Loch Craiglin than in the outside loch diminished in the second year and remained poor thereafter in spite of, or perhaps because of, the intensive fertilizations. The dense phytoplankton and other vegetation raised the $\mathrm{pH}$ at times to levels dangerous to animal life.

\section{REFERENCES}

BARKer, H. A., I935. The culture and physiology of the marine dinoflagellates. Archiv. f. Mikrobiol., Bd. 6, pp. 157-81.

BRAARUD, T., I945. A phytoplankton survey of the polluted waters of inner Oslo Fjord. Hvalrådets Skrifter, No. 28.

Bracher, R., I9I9. Observations on Euglena deses. Ann. Bot., Vol. cxxix, pp. 93-Io8.

Harvey, H. W., I933. On the rate of diatom growth. Fourn. Mar. Biol. Assoc., Vol. xIx, pp. 253-76.

Marshall, S. M., I947. An experiment in marine fish cultivation. III. The plankton of a fertilized loch. Proc. Roy. Soc. Edinburgh, Vol. LxIII, pp. 21-33.

ORR, A. P., I947. An experiment in marine fish cultivation. II. Some physical and chemical conditions in a fertilized sea loch (Loch Craiglin, Argyll). Proc. Roy. Soc. Edinburgh, Vol. LxIII, pp. 3-20.

ZoBeLL, C. E., I935. The assimilation of ammonium nitrogen by Nitzschia closterium and other marine phytoplankton. Proc. Nat. Acad. Sci., Vol. 21, pp. 5I7-22. 